\title{
THE IMPLICATIONS OF BREXIT FOR THE EU'S SECURITY AND DEFENCE ACTORNESS IN THE WORLD
}

\section{Münevver CEBECI* \\ Research Article}

\begin{abstract}
This article aims to elucidate the implications of Brexit for the EU's security and defence actorness. Building on Bretherton and Vogler's conception of "global actorness", it inquires first, into political and security implications, and, second, into defence implications. It argues that Brexit affects the EU's security and defence actorness negatively in terms of its presence (its diplomatic weight and representation) whereas the impact on the Union's defence capabilities might not be detrimental in the long run, despite the loss a Member State with significant military power.
\end{abstract}

Keywords: Brexit, European Union, global actorness, Common Security and Defence Policy

\section{Brexit'in AB'nin Dünyadaki Güvenlik ve Savunma Aktörlüğ̈̈ne Etkileri}

$\ddot{O} z$

Bu çalışmanın amacı Brexit'in AB'nin güvenlik ve savunma aktörlüğü üzerindeki etkilerini irdelemektir. Makale, Bretherton ve Vogler'in "küresel aktörlük” anlayışından yola çıkarak, önce Brexit'in siyasi ve güvenlik ile ilgili etkilerine bakmakta, sonra savunma etkilerini değerlendirmektedir. Makalenin ana argümanı Brexit'in AB'nin güvenlik ve savunma aktörlügüüü uluslararası varlı̆̆ açısından (diplomatik ăgırlık ve temsil boyutlarıla) olumsuz etkilediği, ancak, bu her ne kadar askeri gücü yüksek bir üye ülkenin kaybl anlamına gelse de, Birliğin savunma kabiliyetleri açısından uzun vadede çok da zararlı olmayabileceğidir.

* Prof. Dr., Marmara University, Institute of European Studies; munevvercebeci@marmara.edu.tr ORCID: 0000- 0003-4205-8924 Makalenin Gönderilme Tarihi:30/11/2020, Kabul Edilme Tarihi: 01/03/2021 


\section{Introduction: Defining the EU's global actorness in terms of security and defence}

The implications of Brexit on EU foreign policy, in general, and, on Common Security and Defence Policy (CSDP), in particular, have been widely discussed since 52 per cent of the British electorate decided to leave the EU with a referendum held on 23 June 2016. This article aims to elucidate the implications of Brexit for the EU's security and defence actorness. It pursues a two-pronged approach, inquiring, first, into political and security implications, and, second, into defence implications. Brexit's impact on the EU's actorness in civilian crisis management is deliberately left out of the scope of this study.

Since the late 1970s, a significant number of studies has defined and assessed the EU's global actorness in general and its security actorness in particular ${ }^{1}$. This study takes Bretherton and Vogler's approach to the EU's actorness as its basis in which they refer to the minimal behavioural definition of actorness as the ability to "formulat[e] purposes and mak[e] decisions, and thus engag[e] in some form of purposive action". In their view, the EU's global actorness can be assessed through looking at three factors: opportunity (the external environment of the EU, which either permits it to rise as an actor or limits its ability to display actorness), presence (the ability of the EU to affect other actors' behaviour by only being itself; i.e. being a successful peaceful regional integration project and providing significant welfare to its citizens), and, capability (the internal context of EU action which refers to having diplomatic capacity, instruments and the ability to capitalize on presence $)^{3}$. This article diverges from their approach on one point: they only take the external environment of an actor as opportunity and regard its internal circumstances as part of its capabilities. However, not all internal conditions can be named as capability. For example, German unification cannot be regarded as a capability but it had a crucial impact on the EU as it changed its borders and demography. Eurozone crisis of 2010, which negatively affected the EU's position as a centre of attraction, cannot also be evaluated solely in terms of capability. Brexit is also a similar occurrence which not only changed

1 E.g., Gunnar Sjöstedt, The External Role of the European Community, (Westmead: Saxon House, 1977); Christopher Hill, "The Capability-Expectations Gap, or Conceptualizing Europe's International Role”, Journal of Common Market Studies 31, no 3 (1993): 305-328; Charlotte Bretherton and John Vogler, The European Union as a Global Actor, London and New York: Routledge, 1999; Charlotte Bretherton and John Vogler, "A Global Actor Past Its Peak?", International Relations 27, no 3, 375-390.

2 Bretherton and Vogler,1999, 20.

3 Bretherton and John Vogler, The European Union as a Global Actor, (London and New York: Routledge, 2006): 22. 
the EU's borders but had a crucial impact on its actorness in various ways which go beyond having an impact on capabilities. Thus, this article takes internal factors which cannot solely be seen through the lens of capabilities as part of what Bretherton and Vogler define as "opportunity". However, a more appropriate term to refer to conditions which permit an entity to rise as an actor or limit its ability to display actorness would be "context" rather than "opportunity". Thus, differently from Bretherton and Vogler, this article defines actorness according to the internal and external context within which an actor "acts", its presence, and its capability. Brexit constitutes the context within which the EU's security and defence actorness is evaluated in this article, coupled surely with external factors such as the Trump presidency, the Russian factor, etc.

On the other hand, the EU's security actorness can be elaborated in terms of its security functions, as defined by Waever: "keeping [its] core intact" (ending balance of power and rivalry among Western European powers, desecuritizing relations between France and Germany, thus providing a centre to the continent); exerting a "silent disciplining power on "the near abroad" (exercising power over those countries located in its geographical proximity through the magnetism that its core provides - a function which worked in Central and Eastern Europe); and playing "a potential role as direct intervenor in specific conflicts" (conflict prevention/crisis management). ${ }^{4}$ Waever regards the notion of actorness in conventional International Relations Studies as "problematic" because many analysts take "action" as the major premise to define $i^{5}$. He sees actors as narratively constituted and structured as subjects that act and exert power. ${ }^{6} \mathrm{He}$ argues that although conventional IR does not take the EU as an actor, it can be regarded as one, not only because it "acts" (securitizes, stabilizes other countries, and, performs conflict prevention) but also because there are efforts and talk about the EU that "help constitute [it] as an international actor and thereby structure narratives more and more systematically with the EU as the primary occupant of the role of 'actor' responsible, blamable, the one that makes a difference". ${ }^{7}$ In Waever's view, the EU's "potential role as a direct intervenor in specific conflicts" is its most actor-like function in the conventional sense, as intervention is "something an actor does", but it is also the "the least fulfilled" one as the EU does not

4 Ole Waever, "The EU as a security actor - Reflections from a pessimistic constructivist on post-sovereign security orders", in International Relations Theory and the Politics of European Integration - Power, Security and Community, ed. Morten Kelstrup, and Michael C. Williams (London and New York: Routledge, 2000), 260.

Ibid., 277.

6 Ibid.

7 Ibid., 282. 
perform well in this realm. ${ }^{8}$ Nevertheless, Waever believes that this story of "failure, doubt and ambivalence" also constitutes the EU's actorness, besides its "natural unity and subjectivity" because "[a]n actor is not just a thing, given and easy; it is instead, problematic, critical - a cracked actor". ${ }^{9}$ This article mainly looks at the third security function of the EU that is embodied in its CSDP, as well as the political aspects of its security actorness. In this regard, it is not concerned with the "narratives" that construct the EU as an actor. It focuses on "action" instead, trying to see how Brexit affects the EU's security and defence capabilities.

Combined with Bretherton and Vogler's approach, Waever's definition of the EU's actorness and security functions constitute the major point of departure of this article. The main security function of the EU - "keeping its core intact" - can be read in terms of what Bretherton and Vogler refer to as "presence" because by only being itself - having successfully desecuritized relations among European powers and constituting a zone of welfare - the EU creates a foreign policy impact. This is "unintentional" in terms of displaying international actorness. It was only about achieving peace and economic integration in the continent in the beginning. But this is what gave the EU the capability "to act", i.e. take its initial "unintentional" impact under control and start using it to create "intentional" foreign policy outcomes. Thus, the EU's presence has endowed it with an important instrument: exerting its silent disciplining power over others, especially via conditionality. This pertains to capability in Bretherton and Vogler's analysis. Similarly, the EU's conflict prevention/crisis management function, as defined by Waever, is directly related with the civilian and military capabilities of the CSDP.

This article argues that Brexit affects the EU's security and defence actorness negatively in terms of presence (at least in the short run) whereas its impact on the Union's capabilities might not be detrimental in the long run, despite the loss a Member State with significant military power. The UK's "being in the EU" contributed significantly to the Union's presence, especially because of the former's diplomatic weight and military power. Thus, the void that Brexit has generated cannot easily be filled. However, several factors

Ibid.

9 Ibid., 278-279. Waever's conception of security substantially feeds into such definition of actorness, as it takes security as intersubjective and securitization as a process which starts with a speech act, defining something as a threat to a referent object, and which ends up in the use extraordinary measures against the said threat upon acceptance by an audience (and the ensuing authority granted to the security actor). This definition goes beyond traditional definitions of security which take the state as the only actor and the military sector as the major aspect of security. Ole Waever, "Securitization and Desecuritization", in On Security, ed. Ronnie D. Lipshutz, (New York: Columbia University Press, 1995) 46-86. 
alleviate this loss. First, Brexit has given significant impetus to the efforts for autonomous European defence. Second, the UK had already decreased its involvement in the CSDP for a very long time and its contributions were not commensurate with its military capabilities. In other words, the loss, in practice, might not be that big.

This article has a constructivist ontology in terms of approaching the EU's global actorness but a positivist epistemology in tackling the implications of Brexit for the EU's global security and defence actorness. Following George and Bennett ${ }^{10}$, it mainly draws on process tracing as it seeks evidence of mechanisms and processes to make interpretive claims about how Brexit affects the EU's actorness in terms of presence and capabilities. The primary sources of this article are the EU's official documents, the EP's and the House of Lords' reports on Brexit and the CSDP. Although Brexit is still an on-going and unresolved process in terms of striking a deal between the EU and the UK, a considerable literature has already been formed regarding its impact on the EU's security and defence policies. This article thus draws on a pool of secondary sources which also involve think-tank reports/working papers (that are especially used to enrich process-tracing), besides scholarly articles and books written on the subject. The contribution of this article to the literature is the application of the conceptual framework of global actorness in assessing the impact of Brexit on the CSDP because the existing literature does not provide a conceptual analysis and mainly relies on descriptive and causal inference. This article also uses these methodological tools but it employs them to help interpret the outcomes in terms of the EU's global actorness $^{11}$.

\section{Political and Security Implications of Brexit for the EU's Global Actorness}

With Brexit, the political weight of the EU in international fora will significantly diminish. The most significant example of this is the EU's representation in the United Nations Security Council (UNSC). The UK is one of the five permanent members of the UNSC. With Brexit, France is the only EU member that holds a permanent seat at the UNSC. Because the UNSC decides by concurring votes of the permanent members on non-procedural matters (i.e., the veto system), only one permanent member can veto a decision

${ }^{10}$ Alexander L. George and Andrew Bennett, Case Studies and Theory Development in the Social Sciences, (Cambridge, MA: MIT Press, 2005).

11 On the use of these methodological tools in process-tracing, see: David Collier, "Understanding Process Tracing", Political Science and Politics 44, no 4 (2011): 823-30. 
and this means that legally speaking France's presence still secures the EU's voice. However, in representational terms, having two member states in the UNSC would surely give the EU more weight (especially in supporting a decision). The Union's positions (former common positions) oblige member states to pursue the EU's position in international fora. Furthermore, political solidarity in the EU's external action is one of the principles underlined by the Lisbon Treaty (Article 24), and, accordingly, member states are expected to "refrain from any action which is contrary to the interests of the Union or likely to impair its effectiveness as a cohesive force in international relations" 12 . In this respect, the loss of a second seat at the UNSC would harm the EU's actorness, especially in terms of security and defence.

Another question that is yet to be answered after Brexit is which EU Member State will replace the UK in its role as one of the dominant actors in its foreign and security policies. This is a crucial question in several respects. The first one is about the Transatlaticist-Europeanist divide regarding the future shape of European defence ${ }^{13}$. The UK was the leading Transatlanticist country in the EU, blocking Europeanist ambitions on various occasions. Considerable examples of this were: its opposition to the EU's creation of autonomous headquarters, the strengthening of institutional structures of the European Defence Agency (EDA) and increasing its budget ${ }^{14}$. In this respect, the UK was seen as the only EU Member State that could counter France's Europeanist drive. In many cases, it also mediated between the two sides of the divide, as was the case in the Tervuren affair ${ }^{15}$. Poland could be in a position in taking the lead as a Transatlancist member in the EU, however, the recent democratic backslide in the country has diminished its credibility considerably and thus it is no longer in a position to be affecting the EU's foreign and security policies. The lack of a member state to replace the UK's role as a leading Transatlanticist country has tilted the balance in the Europeanists' favour in the EU - i.e., it gave significant impetus to the EU's

12 European Commission, "Consolidated Version of the Treaty on European Union", Official Journal of the European Union, C 326/1, October 26, 2012.

13 Transatlaticists see NATO as the primary defence institution in Europe and insist that it should remain as the first resort in European defence whereas Europeanists seek more autonomy for the EU in this regard.

14 Anne Bakker, Margriet Drent and Dick Zandee, "European defence: how to engage the UK after Brexit?", Clingendael Report, July 2017, 15. Accessed on May 19, 2019, https://www.clingendael.org/sites/default/files/2017-

07/Report_European_defence_after_Brexit.pdf.

15 See footnote 56 for more on the Tervuren affair. 
efforts for autonomous defence. Many analysts claim that Brexit might not necessarily be a negative development for European defence ${ }^{16}$.

The second aspect is the issue of co-leadership. France and the UK had been the co-leaders CSDP from the St. Malo summit of 1998 to mid-2000s. The Franco-British St. Malo summit was significant as it paved the way for the creation of the European Security and Defence Policy. ${ }^{17}$ At another summit, the Le Touquet Summit of February 2003, France and Britain agreed on the Battle Groups initiative - an initiative that would enable the EU "to conduct several operations simultaneously and to improve its rapid reaction capacity" ${ }^{\prime 18}$. Nevertheless, after this, Britain started pursuing a different stance,

16 E.g.: Sven Biscop, "All or nothing? The EU Global Strategy and defence policy after the Brexit”, Contemporary Security Policy 37, no 3 (2016): 431-445; François Heisbourg, "Brexit and European Security", Survival 58, no 3 (2016): 13-22; François Heisbourg, "Europe's Defence: Revisiting the Impact of Brexit",

Survival 60, no 6(2018) 17-26; Lorenzo Angelini, Brexit is an opportunity for EU defence policy", EU Observer, July 8, 2016. Accessed on April 23, 2020, https://euobserver.com/opinion/134256.

17 British Prime Minister Tony Blair and French President Jacques Chirac met at a summit held in St Malo on December 3-4, 1998, and declared that the EU should have the "capacity for autonomous action, backed up by credible military forces, the means to decide to use them, and a readiness to do so, in order to respond to international crises". It was only after St. Malo declaration that the EU could decide on the creation of the European Security and Defence Policy (ESDP) at its June 1999 Cologne European Council. St. Malo was significant because the UK dropped its long-lasting opposition to the creation of an autonomous European defence capability on condition that this would not work at the expense of NATO. There were two major reasons for the shift in British foreign policy. The first one was the EU's failure to act in the Balkan crises and the second one was the change of government in Britain. The grave consequences of the Balkan crises led to a realization that the EU should do more on security and defence and take on more responsibility. Second, the newly elected Blair government wanted to engage more with the EU. The UK was already out of the European Monetary Union and the Schengen Area. Thus, it needed to show its credibility and leadership in another EU policy area. The prospective ESDP seemed to be a perfect fit because at the same time the UK needed to control the creation of an autonomous European capability so that it would not develop in Europeanist ways. "Joint Declaration on European Defence", Joint Declaration of the Heads of State and Government of France and the United Kingdom issued at the British-French Summit, St Malo, 3-4 December 1998, https://www.cvce.eu/content/publication/2008/3/31/f3cd16fb-fc37-4d52936f-c8e9bc80f24f/publishable_en.pdf.

18 European Union Institute for Security Studies - EU-ISS, "Franco-British Summit - Le Touquet, 4 February 2003", From Copenhagen to Brussels - European defence: core documents, Volume IV, Chaillot Papers 67 (December 2003): 38. Note that later, Germany also joined the two countries in detailing the Battle Groups Concept. A food for thought paper was issued by the three states in February 2004. The concept was adopted as part of the Headline Goal 2010 by the General Affairs Council in May 2004 and endorsed by the European Council in June, the same year. Gustav Lindstrom, "Enter the Battle Groups", Chaillot Papers 97 (February 2007): 11-12. 
gradually decreasing its contribution to the ESDP/CSDP. Whitman depicted this as: "Since the high point of the 1998 Anglo-French summit in St. Malo, the UK's position on the development of an EU defence policy and capability has shifted from being a leader to a laggard." 19 In his view, the CSDP "has not been a core component of British security and defence planning over the last decade" and, significantly, "the UK's most recent five-year 'strategic defence and security review' made no reference to the CSDP as a component of the UK's approach to providing for its national security and defence". ${ }^{20}$ In other words, for more than a decade, Britain was not playing the co-leadership role in the $\mathrm{CSDP}^{21}$, but rather acting in ways which would block further autonomy in this policy realm. ${ }^{22}$

However, for various institutional reasons, co-leadership is an important driver in CSDP. ${ }^{23}$ Thus, the question concerning which country will pursue the co-leadership of the CDSP with France and, also, balance France's ambivalent stance regarding the CSDP has been widely discussed after Brexit. Germany seems to be the only country in the EU that might be able to replace the UK in terms of its weight in this realm. Some analysts already claim that France and Germany are now leading European defence. Major and Mölling argue that "Paris and Berlin are the indispensable leaders of, and the backbone for, European defence" and "beyond political gravitas, they represent about 50 per cent of military and industrial capabilities within the EU after Brexit and about 40 per cent of those in wider Europe" ${ }^{24}$.

19 Richard Whitman, "Defence on the Brexit frontline", Open Democracy, 11 March 2016. Accessed on April 23, 2019, https://www.opendemocracy.net/en/brexit-divisions/defenceon-brexit-frontline/.

20 Ibid.

21 Turpin argues that the the UK's disengagement from the ESDP became visible under the premiership of Gordon Brown in 2007. The UK was more concerned with its engagement in Iraq and Afghanistan whereas the EU's major concern was the crises in Africa. Lee David Turpin, "UK-EU Military Cooperation and Brexit from a Neoclassical Realist Perspective: No Big Deal?", in Peace, Security and Defence Cooperation in Post-Brexit Europe - Risks and Opportunities, ed.s Cornelia-Adriana Baciu and John Doyle, (Cham: Springer Nature, 2019): 11.

22 Biscop, "All or nothing?", 431-32.

23 This is mainly because, even in the intergovernmental CSDP realm, the EU has a very complex, multi-actor decision/policy-making system which resists "clear hierarchies and, above all, the dominance of one single actor". Tuomas Iso-Markku and Gisela MüllerBrandeck-Bocquet, "Towards German leadership? Germany's Evolving Role and the EU's Common Security and Defence Policy", German Politics 29, no 1 (2020): 60-61.

24 Claudia Major and Christian Mölling, "Franco-German Differences Over Defense Make Europe Vulnerable",

Judy Dempsey's Strategic Europe, March 29, 2018. Accessed on August 30, 2019, https://carnegieeurope.eu/strategiceurope/75937. 
Germany redefined its security policy in 2016 with the White Paper on German Security Policy and the Future of the Bundeswehr, declaring its willingness to take more responsibility in European crisis management. ${ }^{25}$ Nevertheless, the German public still seems reluctant (albeit at a lower rate) regarding Germany's engagement in international crises. In 2019, a survey conducted by Körber-Stiftung demonstrated that 49 per cent of the German public was of the view that Germany should continue to hold back from engaging more in international crises while 43 per cent was in favour of further engagement ${ }^{26}$. Iso-Markku and Müller-Brandeck-Bocquet argue that Brexit, coupled with other factors such as Donald Trump's ambivalent behaviour regarding Transatlantic relations, has "given impetus to FrancoGerman shared leadership in the CSDP". ${ }^{27}$ They further contend that the international community also welcomed their co-leadership, although it remains unclear whether this will be long-lasting because the two countries also have major divergences in their approach to the CSDP. ${ }^{28}$

France and Germany diverge on several issues even though they currently have pro-European leaders, a significant facilitating factor in reaching agreement on the future of Europe. The first point of divergence is their approach to European defence. Germany prefers a normative approach whereas the French approach is pragmatic, "which sees the EU as just one framework for delivery among many" 29 . The second point was about the shape that PESCO would take as Germany insisted on an inclusive framework despite French preference for keeping it exclusive. ${ }^{30}$ This was resolved through the adoption of an inclusive framework as Germany preferred ${ }^{31}$. Because the activation of PESCO did not meet French expectations, France created the European Intervention Initiative (EII/EI2) that would be developed

25 The Federal Government, "The White Paper on German Security Policy and the Future of the Bundeswehr", July 13, 2020. Accessed on October 29, 2020, https://issat.dcaf.ch/download/111704/2027268/2016\%20White\%20Paper.pdf.

26 Körber-Stiftung, "Einmischen oder zurückhalten? Eine repräsentative Umfrage im Auftrag der Körber-Stiftung zur Sicht der Deutschen auf die Außenpolitik", (2019), https://www.koerber-stiftung.de/fileadmin/user_upload/koerberstiftung/redaktion/handlungsfeld_internationaleverstaendigung/pdf/2019/Umfrage_Einmischen oder_zuru ckhalten.pdf.

27 Iso-Markku and Müller-Brandeck-Bocquet, “Towards German leadership?”, 72.

28 Ibid. Iso-Markku and Müller-Brandeck-Bocquet list the establishment of the Military Planning and Conduct Capability (MPCC) and the activation of PESCO as "the most prominent examples" to Franco-German leadership in the CSDP.

29 Major and Mölling, "Franco-German Differences".

30 Ibid.

31 Ibid. 
outside the EU. The EII was proposed by France in September $2017^{32}$ and agreed at the Council meeting of EU Defence Ministers on June 25, 2018, by its ten participating states ${ }^{33}$. The EII is composed of states which are "politically willing and militarily capable" 34 to intervene in international crises and it aims at creating a common "strategic culture" ${ }^{35}$. The UK (now outside the EU) and Denmark (which has an opt-out from the CSDP) are also among the participating states. The creation of the EII initially caused contention between France and Germany. Obviously, France was responding to the development of PESCO as an inclusive and modular framework by creating an exclusive defence initiative outside the EU. ${ }^{36}$ Germany was reluctant about the development of such a framework as it preferred the development of a common strategic culture within the Union, including all Member States. ${ }^{37}$ This divergence was finally resolved by the Franco-German Meseberg Declaration of June 19, 2018, where the two countries agreed "to further develop the emergence of a shared strategic culture through the European Intervention Initiative, which will be linked as closely as possible with PESCO".38

On the other hand, there are not many other alternatives among EU Member States to take on co-leadership role or to balance the dominance of France in CSDP, if Germany becomes reluctant. Italy's defence spending

32 France Diplomacy, "President Macron's Initiative for Europe: A sovereign, united, democratic Europe", September 26, 2017. Accessed on October 25, 2019, https://www.diplomatie.gouv.fr/en/french-foreign-policy/europe/news/article/presidentmacron-s-initiative-for-europe-a-sovereign-united-democratic-europe.

33 Belgium, Denmark, Estonia, France, Finland, Germany, the Netherlands, Portugal, Spain and the United Kingdom.

34 As defined by French Defence Minister Florence Parly. France 24, "Nine EU countries sign up for European military intervention plan”, June 25, 2018. Accessed on October 25, 2019, https://www.france24.com/en/20180625-nine-eu-countries-sign-european-militaryintervention-plan.

35 Dick Zandee Kimberley Kruijver, "The European Intervention Initiative: Developing a shared strategic culture for European defence", Clingendael Report, (September 2019), 2. Accessed on October 29, 2019, https:/www.clingendael.org/sites/default/files/201909/The European Intervention_2019.pdf.

36 This also testified to Major and Mölling's argument that France saw "the EU as just one framework for delivery among many". Major and Mölling, "Franco-German Differences".

37 Frédéric Mauro, "The European Intervention Initiative: Why we should listen to German Chancellor Merkel", IRIS Tribune, July 16, 2018. Accessed on October 29, 2019, https://www.iris-france.org/115776-the-european-intervention-initiative-why-we-shouldlisten-to-german-chancellor-merkel/.

38 Élysée, "Meseberg Declaration - Renewing Europe's promises of security and prosperity", June 19, 2018. Accessed on October 29, 2019, https://www.elysee.fr/emmanuelmacron/2018/06/19/meseberg-declaration-renewing-europes-promises-of-security-andprosperity.en. 
(1.2 per cent of its $\left.\mathrm{GDP}^{39}\right)$ and limited capacity makes it rather difficult for the country to exhibit such actorness. Another big EU country that could replace the UK's position in the EU was Poland, the defence spending of which amounts to 2 per cent of its GDP ${ }^{40}$. However, it cannot perform such actorness because of its democratic backslide. Furthermore, Poland lacks the necessary navy and air capabilities and experience in commanding multinational operations (and providing headquarters) for displaying the same kind of actorness.

Another crucial political-security impact of Brexit is the loss of the UK's diplomatic expertise which has so far been indispensable for the CSDP. Diplomatic capability is vital for preparing the ground for and backing up crisis management operations. The geopolitical orientation and experience of British diplomats and the UK's diplomatic and historical links with numerous countries have significantly contributed to the CSDP. ${ }^{41}$ A Study by the European Parliament (EP) cites the EUNAVFOR Atalanta as an example, contending that the success of the mission was partly due to "the diplomatic work carried out by London" ${ }^{2}$. The EP Study claims that British diplomacy was vital in persuading Kenya and the Seychelles - both Commonwealth countries - to sign "judicial cooperation agreements" with the EU so that "pirates arrested could be tried and imprisoned in these countries, rather than released shortly after their arrest". ${ }^{43}$ This is how EUNAVFOR Atalanta "started to produce good results" 44 . On the other hand, in many cases, the UK also had a mediating role between the US and the $\mathrm{EU}^{45}$. It remains unclear if this role will be taken on by another EU Member State. Macron's endeavour to play some role in this regard cannot provide the weight that the UK had,

39 NATO, "Defence Expenditure of NATO Countries (2013-2019)", Press Release, November 29, 2019, 8. Accessed on April 23, 2020. https://www.nato.int/nato_static_fl2014/ assets/pdf/pdf_2019_11/20191129_pr-2019-123-en.pdf.

40 Ibid.

41 Cf. Malcolm Chalmers, "Brexit and European Security", RUSI Briefing Paper, (February 2018), 6. Accessed on October 29, 2019, https://rusi.org/sites/default/files/ 20180223_malcolm_brexit_security_v4.pdf.

42 European Parliament, "CSDP after Brexit: the way forward", Study, May 2018, 33. Accessed on April 2020 https:/www.europarl.europa.eu/RegData/etudes/STUD/2018/603852/EXPO_STU(2018)6 03852_EN.pdf.

43 Ibid.

44 Ibid.

45 Benjamin Martill and Monika Sus, "Post-Brexit EU/UK security cooperation: NATO, CSDP+, or 'French connection'?", The British Journal of Politics and International Relations 20, no 4 (2018): 858. 
especially if France's historically ambivalent approach towards the US is considered. ${ }^{46}$

Other crucial ingredients of the UK's diplomatic power are its intelligence and humanitarian aid capabilities. These are essential for early warning and policy planning in crisis situations, especially for designing proactive policies oriented towards conflict prevention. The EU had significantly benefited from the UK's power in these realms. All in all, the UK's expertise in foreign, security and defence policies can be regarded as one of its major contributions to the EU. ${ }^{47}$ Thus, the loss of such capabilities has a significant limiting impact on the EU's actorness.

\section{Defence Implications of Brexit for the EU's Global Actorness}

The UK is one of Europe's largest military forces and one of the two nuclear powers in the continent. It is also one of the two countries in Europe that are able to deploy the full spectrum of military capabilities. ${ }^{48}$ The major debate on Brexit's implications for the EU's global actorness has revolved around whether it would create a vacuum in European defence. Some analysts have argued that contrary to negative expectations, the EU could achieve further integration in the long run and the CSDP could acquire a more autonomous basis in terms of having defence capabilities independent from NATO and the USA. ${ }^{49}$ In 2018, the then President of European Commission, Jean-Claude Juncker, underlined the need for making the European Defence Fund and Permanent Structured Cooperation "fully operational". ${ }^{50}$ Juncker tied this endeavour to the EU's becoming "a more sovereign actor". ${ }^{51} \mathrm{His}$ approach testified to those claims that the efforts for autonomous European defence would accelerate after Brexit.

A significant implication of Brexit concerns European defence spending. The UK spent $£ 46,861$ billion for defence in 2019 and this corresponds to 2.14 per cent of its gross domestic product (GDP). ${ }^{52}$ This makes the UK the

46 Ibid.

47 See, e.g. Turpin, "UK-EU Military Cooperation and Brexit”, 14.

48 Martill and Sus, "Post-Brexit EU/UK security cooperation", 849.

49 E.g., Sven Biscop, "Brexit, Strategy, and the EU: Britain Takes Leave”, Egmont Papers 100, (2018), 10-11.

50 European Commission, "State of the Union 2018 - The Hour of European Sovereignty", September 12, 2018, 5. Accessed on May 19, 2020, https://ec.europa.eu/commission/sites/beta-political/files/soteu2018-speech_en.pdf.

51 Ibid.

52 NATO, "Defence Expenditure of NATO Countries (2013-2019)", 6-8. The UK Ministry of Defence gives these numbers as $£ 38$ billion and 2.1 per cent of GDP. See, The UK Ministry 
fourth country in NATO that spends the most on defence in terms of its percentage to the GDP and the third country in Europe to meet NATO's defence spending goal of 2 per cent set by the Wales Summit of $2014 .^{53}$ With Brexit, the share of non-EU countries has increased exponentially in Transatlantic burden-sharing. This situation has put growing pressure on EU Member States to spend more on defence.

Although the UK was rather reluctant about EDA's institutional development and opposed to an increase in its budget; it had still been one of the main financial contributors to it and provided "highly qualified officials to serve in the EDA", including its first Chief Executive, Nick Whitney. ${ }^{54}$ This means that with Brexit, the 26 Member States of EDA (Denmark has an optout) have to finance the part that was covered by the UK. On a positive note, despite this increase in the burden of Member States, EDA budget did not decrease, to the contrary, there was a gradual increase in its budget (after the UK opposition was removed) from $€ 30,75$ million in $2016^{55}$ to $€ 35,3$ million in 2019, and an estimated $€ 37,03$ million in 2020 (with an amendment to the original estimate of $€ 36,5$ million $)^{56}$.

From an operational perspective, the UK has considerable capability and experience in commanding and providing headquarters for multinational operations. Therefore the loss of an important defence actor with strategic capabilities has negative implications for the EU. The issue of headquarters is significant because the UK always opposed the idea of creating autonomous European headquarters as this meant the duplication of NATO assets and capabilities and the development of European strategic autonomy which could lead to a rivalry between the EU and NATO at some point ${ }^{57}$. An important

of Defence, "UK Defence in Numbers - 2019”, (2019), 3. Accessed on April 23, 2020. https://assets.publishing.service.gov.uk/government/uploads/system/uploads/attachment_d ata/file/869612/20200227_CH_UK_Defence_in_Numbers_2019.pdf

53 Ibid.

54 Bakker, Drent and Zandee, "European defence", 15. The UK also contributed to the Athena mechanism by providing 15.5 per cent of its funding. European Parliament, "CSDP after Brexit", 33.

55 European Defence Agency, "2016 Annual Accounts”, June 30 2017, 4. Accessed on May 18, 2019, https://eda.europa.eu/docs/default-source/finance-documents/eda-2016-annualaccounts.pdf.

56 European Defence Agency, "Finance", 2020. Accessed on October 29, 2020, https://eda.europa.eu/Aboutus/who-we-are/Finance.

57 This evokes the Tervuren Affair when France, Germany, Belgium and Luxembourg decided at an informal summit in 2003 that the EU should have its autonomous headquarters, and later the UK persuaded them not to proceed with this idea as it would mean rivalling NATO. The solution found was three-fold: (1) the creation of an EU military cell within NATO Headquarters (Supreme Headquarters Allied Powers Europe - SHAPE) in Mons, Belgium 
example of British opposition was the then British Foreign Minister William Hague's 2011 statement that the creation of autonomous European Headquarters was a red line for the UK. On the other hand, made its national headquarters available to the EU and commanded several CSDP operations. These had significantly contributed to the EU's global actorness both in terms of its presence and capabilities. With Brexit, the EU NAVFOR's operational headquarters based in the UK's Northwood Headquarters in Hertfordshire, Eastbury, were moved to Spain's Rota base in Cádiz and France's Brest base on March 29, 2019.

The UK was contributing to the EU Force Catalogue nominally and it had made significant contributions to many EU operations ${ }^{58}$ in terms of providing personnel, equipment, and headquarters, as well as expertise. An important part of displaying global actorness depends on having naval capabilities. The UK's Royal Navy had been one of the world's greatest until the 2000s. Even though the Royal Navy was at a low point in terms of its equipment and its power projection capability when the Brexit referendum took place in $2016^{59}$, its naval power still formed an important part of the EU's naval capabilities. The UK led the EUNAVFOR Atalanta and provided headquarters to it. Furthermore, its overseas military bases had provided significant potential for the EU's projection of military power in various parts of the world, backing up its naval contributions. The UK's Air Force contributions had been crucial to CSDP as well because it was one of the few countries in the EU that maintained strategic airlift capability. It possessed approximately 50 per cent of all heavy transport aircraft, as well as about 25 per cent of all heavy transport helicopters among the $28 \mathrm{EU}$ member states. ${ }^{60}$

that would act as the EU's operational planning unit in EU operations which would be conducted with the use of NATO assets and capabilities (under the Berlin Plus arrangements); (2) the establishment of an autonomous EU civil-military planning cell would be established within the EU Military staff to act as headquarters in EU-only operations (EU operations that would be conducted without the use of NATO assets and capabilities); and (3) continuing the ad hoc creation of national headquarters for EU-only operations (especially when there is a framework/lead nation for conducting the operation).

58 It was the fifth among the top contributors to CSDP military operations, after France, Italy, Germany and Spain. Giovanni Faleg, "The Implications of Brexit for the EU's Common Security and Defence Policy". CEPS Policy Contribution. July 26, 2016. Accessed on August 15, 2019. https://www.ceps.eu/ceps-publications/implications-brexit-eus-commonsecurity-and-defence-policy/.

59 David Axe, "Commentary: What the U.S. should learn from Britain's dying navy", Reuters, October 14, 2016. Accessed on August 30, https://www.reuters.com/article/us-uk-militarynavy-commentary-idUSKCN10L1AD

60 Bastian Giegerich and Christian Mölling, “The United Kingdom's contribution to European security and defence", DGAP External Publications, February 2018, 7. Accessed on October 20 , 
The UK's intelligence capabilities are also advanced and it had significantly contributed to EU operations. It UK held approximately " $50 \%$ of all combat intelligence, surveillance and reconnaissance heavy unmanned aerial vehicles (CISR UAVs) and about $40 \%$ of all electronic-intelligence aircraft of the 28 EU member states" ${ }^{\prime 61}$. British land forces had also been deployed in various EU missions but the numbers were not commensurate with the UK's military power. As of 2018, the United Kingdom's contribution to the military operations of the EU was estimated as 3.6 per cent of the total. ${ }^{62}$ This was surely not commensurate with the size of its military capabilities. However, beyond its physical contribution, the military expertise and experience that the UK provided and diplomacy with which it backed the CSDP was strategic and thus essential.

\section{The EU's efforts to offset the negative impact of Brexit}

Brexit, coupled especially with the developments in the EU's immediate neighbourhood, has compelled the EU to seek ways for displaying more effective security and defence actorness. To deal with these challenges, the EU has developed several mechanisms. The announcement of the Global Strategy in 2016 and the activation of PESCO in 2017 were the initial and most important steps taken after Brexit to strengthen the EU's security and defence policies and move towards strategic autonomy. In 2017, Coordinated Annual Review on Defence (CARD) and the European Defence Fund (EDF) were created as new initiatives for arms procurement and the development of defence industry in Europe. Autonomous EU headquarters for non-executive operations (the Military Planning and Conduct Capability - MPCC) was also established in June 2017.

PESCO, CARD and the EDF are designed in such a way to enable the EU member states to develop and harmonize their defence capabilities and they are complementary and mutually reinforcing tools. ${ }^{63}$ PESCO, introduced by the Lisbon Treaty, was finally launched in 2017 to contribute to the EU's

https://gap.org/system/files/article_pdfs/the_united_kingdoms_contribution_to_european security_and_defence.pdf.

61 Ibid., 6.

${ }^{62}$ European Parliament, "CSDP after Brexit", 33. Note that some analysts refer to this number as 4.3 per cent for $2007-2015$. See, e.g., Martill and Sus, "Post-Brexit EU/UK security cooperation", 849 .

63 European External Action Service, "Permanent Structured Cooperation - PESCO", Factsheet, June 2018. Accessed on August 13, 2018, https://eeas.europa.eu/sites/eeas/files/pesco factsheet_22-06-2018_2.pdf. 
strategic autonomy by enhancing defence cooperation, joint investment and operational readiness among participating EU Member States. ${ }^{64}$ Initially, PESCO was to be composed of "those Member States whose military capabilities fulfil higher criteria and which have made more binding commitments to one another in this area with a view to the most demanding missions" ${ }^{\prime 65}$. Nevertheless, it was revised and extended into an inclusive framework with 25 participating Member States ${ }^{66}$. The launch of PESCO was envisaged in the Global Strategy as a way to make the CSDP more responsive. ${ }^{67}$ On June 22, 2017, the European Council decided that PESCO should be activated. The next step taken for the launch of PESCO was 23 Member States' declaration of their willingness to participate in PESCO in a notification to the High Representative and the Council on November 13. Ireland and Portugal joined on 7 December. Malta and Denmark remained outside. Finally, PESCO was activated by the Council on December 11, to be welcomed by the European Council on December 14-15.

PESCO is designed as a project-based initiative. Since March 6, 2018, it has developed 47 projects (one of which is completed) ${ }^{68}$. Some of the PESCO projects are European Medical Command, Military Mobility, CBRN Surveillance as a Service, European Attack Helicopters TIGER Mark III, Maritime Unmanned Anti-Submarine System, and EU Cyber Academia and Innovation Hub. Under PESCO, the participating Member States are developing their defence capabilities jointly and they are expected to make them available to the EU's military operations. PESCO's commitments are binding on the participating Member States. Unanimity is the rule in PESCO decision-making, but only PESCO participants can vote. ${ }^{69}$ PESCO uses Qualified Majority Voting (i.e. the Community method) when accepting new

${ }^{64}$ European External Action Service, “The European Union's Global Strategy: three years on, looking forward", June 2019, Accessed on October 29, 2019, https://eeas.europa.eu/sites/eeas/files/eu_global_strategy_2019.pdf.

65 Lisbon Treaty, Article 42(6). European Commission, "Consolidated Version of the Treaty on European Union".

66 Major and Mölling, "Franco-German Differences".

67 European External Action Service, "Shared Vision, Common Action: A Stronger Europe A Global Strategy for the European Union's Foreign and Security Policy”, June 2016, 11. $\begin{array}{llll}\text { Accessed } & \text { An 2016, }\end{array}$ https://eeas.europa.eu/archives/docs/top_stories/pdf/eugs_review_web.pdf.

68 European External Action Service, "Permanent Structured Cooperation - PESCO", Factsheet, (November 2020), 2. Accessed on November 27, 2020, https:/eeas.europa.eu/sites/eeas/files/pesco_factsheet_2020-11-9-version-20-nov.pdf.

69 Lisbon Treaty, Article 46(6). European Commission, "Consolidated Version of the Treaty on European Union". 
participants and deciding on the suspension of participation. PESCO's secretarial work is conducted jointly by EDA, EEAS and the Military Staff.

CARD is run by the EDA - as its secretariat - and it aims to systematically monitor defence expenditure plans of the Member States and deepen defence cooperation among them in a more structured way and "based on greater transparency, political visibility and commitment". ${ }^{70}$ CARD was based on a trial methodology in 2017-2018 that consisted of initial preparations and information analysis about Member States' possible contributions. ${ }^{71}$ After the completion of the trial run, the first full CARD cycle started in September 2019. ${ }^{72}$ CARD is a significant initiative for capability development; envisaged to contribute to the EU's strategic autonomy. PESCO is expected to develop projects that increase the EU's capabilities in priority areas through the CARD.

The EDF started operating in 2017, to coordinate national investments in defence and achieve interoperability among the Member States through "cooperation in the fields of defence technology and equipment". ${ }^{73}$ PESCO projects are also supported - and, when necessary financed - by the EDF. A budget envelope of $€ 590$ million was allocated to support European defence cooperation, under the current budget period. ${ }^{74}$

With Brexit, the idea of autonomous European Headquarters was also rekindled. In September 2016, in his "The State of the Union" address, the then President of the European Commission, Jean Claude Juncker, called for the EU Member States to establish single headquarters (instead of the existing threefold nature of the headquarters $)^{75}$. For this, on June 8, 2017, the MPCC was established within the EU Military Staff. The MPCC is "a permanent

70 European Defence Agency, "Coordinated Annual Review on Defence (CARD)", 2020, Accessed on April 23, 2020, https://www.eda.europa.eu/what-we-do/our-currentpriorities/coordinated-annual-review-on-defence-(card).

71 Ibid.

72 European Defence Agency, “Annual Report 2019”, 2020, 8. Accessed October 29, 2020, https://www.eda.europa.eu/docs/default-source/eda-annual-reports/eda-2019-annualreport.

73 European Commission, "European Defence Fund”, Factsheet, March 19, 2019, 1. Accessed on: $\quad$ October $\quad 29, \quad 2019$, https://ec.europa.eu/docsroom/documents/34509/attachments/1/translations/en/renditions/n ative.

74 Ibid, 3.

75 European Commission, "State of the Union Address 2016: Towards a better Europe - a Europe that protects, empowers and defends", September 14, 2016. Accessed on October 29, 2019, https://ec.europa.eu/commission/presscorner/detail/en/SPEECH_16_3043. For the threefold nature of CSDP headquarters, see footnote 56 . 
command and control structure at the military strategic level" and is set to deliver the task of "operational planning and conduct of non-executive missions". ${ }^{76}$ With the decision of the Council of Ministers in 2018, the executive tasks of the EU Operations Centre (OPSCEN) were integrated into the MPCC "to be ready by the end of 2020 to take responsibility for the operational planning and conduct of the non-executive military CSDP missions and one executive military CSDP operation limited to EU Battlegroup size" 77 . This means that the MPCC is not a full-fledged operational headquarters able to conduct most demanding military crisis management operations but its creation has symbolic value, especially after Brexit.

All these initiatives are regarded as mechanisms that will provide impetus to the EU's efforts in attaining strategic autonomy and offset the negative impact of Brexit. They are expected to lead to greater coordination in areas such as defence investments, capability development and operational readiness, reducing the differences among member states' weapons systems and increasing interoperability. These developments have taken place without any prejudice to Member States' sovereignty. In a factsheet prepared by the EEAS, it is underlined that PESCO does not undermine the sovereignty of member states and that to the contrary, it will strengthen their strategic autonomy. ${ }^{78}$ This demonstrates that sovereignty in the areas of foreign policy, security, and defence is still very important and indispensable for the Member States. Thus, mechanisms such as PESCO can only be developed and made operational if the member states have the political will and the desire to make them function. In other words, the member states' political will is the major determining factor for the effectiveness of the EU's security and defence policies.

\footnotetext{
76 European External Action Service, "The Military Planning and Conduct Capability (MPCC)", November 2018. Accessed on May 19, 2019. https://eeas.europa.eu/sites/eeas/files/mpcc_factsheet_november_2018.pdf. Non-executive missions are mainly training and observation missions.

77 Council of the European Union, "Council conclusions on Security and Defence in the context of the EU Global Strategy - Council Conclusions (19 November 2018)", Brussels, 13978/18, November 19, 2018, 4. Accessed on October 25, 2020, https://data.consilium.europa.eu/doc/document/ST-13978-2018-INIT/en/pdf. The EU Battlegroup size is 1500 troops.

78 European External Action Service, "Permanent Structured Cooperation” 2018.
} 


\section{The UK's Possible Involvement in CSDP}

With Brexit, the UK has become a third country and a neighbour to the EU. This means that it is no longer part of EU decision-making, i.e. it no longer has voting rights in the EU. This surely includes the Common Foreign and Security Policy (CFSP) - thus, the CSDP. The UK is no longer represented in CSDP institutions such as the Political and Security Committee, working groups and agencies such as the EDA, EU Institute for Security Studies (EU-ISS), Satellite Centre etc. It cannot appoint staff to them either. The UK is expected to disengage from CSDP missions if no deal is made till the end of the transition period - December 31, 2020. ${ }^{79}$ The UK will have access to the Galileo Programme (the EU's Global Satellite Navigation System), but it will not be able to use it for defence or critical national infrastructure and it will not have any say over decisions relating to this Programme, although it played a leading role in its creation ${ }^{80}$. Furthermore, UK citizens will not be able to bid for Galileo contracts.

The UK might join PESCO as a third country under certain conditions. ${ }^{81}$ When a third country requests to participate in a specific project, first, the project members evaluate the request, and if they agree positively, then the project coordinator submits the request to the Council. At the Council, 25 PESCO participating the Member States, acting unanimously, decide on the third country's participation. The decision about the UK's involvement will depend on whether a Brexit deal is reached. In case of a deal, its involvement can benefit both sides. However, without any decision-making rights, the UK might not be willing to join.

During the transition period which started on February 1, 2020, the UK has been bound by CFSP/CSDP decisions (including sanctions or CFSP/CSDP statements) and international agreements concluded by the EU

${ }^{79}$ Britain officially notified the EU on October 31, 2020 that it would withdraw from EU military missions by the end of 2020. Reuters, "Britain confirms withdrawal from EU military missions, diplomats say", October 21, 2020. Accessed on October 29, 2020, https://www.reuters.com/article/uk-britain-eu-defence-idUSKBN2761VU.

${ }^{80}$ Gov.uk, "Participating in EU satellite and space programmes from 1 January 2021", October 9, 2020. Accessed on October 29, 2020, https://www.gov.uk/guidance/satellites-and-spaceprogrammes-from-1-january-

2021\#: :text=The $\% 20$ UK\%20will\%20not $\% 3 \mathrm{~A}$,in $\% 20$ the $\% 20$ development $\% 20$ of $\% 20$ Gali leo.

81 European Commission, "Council Decision (CFSP) 2020/1639 of 5 November 2020 establishing the general conditions under which third States could exceptionally be invited to participate in individual PESCO projects", Official Journal of the European Union, November 6, 2020. Accessed on November 14, 2020, https://eurlex.europa.eu/eli/dec/2020/1639/oj. 
although it is no longer represented in EU bodies. ${ }^{82}$ The UK can negotiate and sign international agreements, on condition that they will enter into force after the transition period. ${ }^{83}$ Furthermore, the UK is expected to refrain from any act which might prejudice the EU's or its Member States' interests. ${ }^{84}$ The UK can only refrain from applying a CFSP/CSDP decision if it notifies the High Representative "for vital and stated reasons of national policy". ${ }^{85}$ In this transition period, the UK cannot also serve as the lead/framework nation of any CSDP operations or provide commanders or headquarters to them ${ }^{86}$. It cannot also lead a Battle Group in an EU operation.

Because the UK is no longer bound by the EU Treaties, the mutual defence clause ${ }^{87}$ and the solidarity clause ${ }^{88}$ will no longer apply. Thus, in case of an armed or terrorist attack on or a natural or man-made disaster in an EU Member State, the UK is no longer supposed to be helping the country concerned. Similarly, EU Member States will also have no obligation towards the UK to come to its rescue if it is the victim of an attack or a disaster. It can no longer join EU operations, if it is not an operation conducted with NATO assets and capabilities, and, in case of an EU-only operation, if it is not invited by the Council, acting unanimously.

Now that Britain is a third country, its status regarding the CSDP is similar to that of Turkey, as well as to Norway, Iceland, Albania and Montenegro: i.e., they are non-EU European NATO members/Allies. Non-EU European Allies can get involved in the CSDP through a security agreement ${ }^{89}$ and they can also join the work of EDA through an administrative

${ }^{82}$ Article 129.1 and .2 of the Withdrawal Agreement. The withdrawal agreement stipulated that in exceptional cases, the Union could invite the UK to attend meetings of such bodies if it considers the UK's participation necessary. Article 129.2 (b). European Commission, "Agreement on the withdrawal of the United Kingdom of Great Britain and Northern Ireland from the European Union and the European Atomic Energy Community", Official Journal, 2019/C 384 I/1, November 12, 2019. Accessed on November 30, 2019, https://eurlex.europa.eu/legal-content/EN/TXT/PDF/?uri=CELEX:12019W/TXT(02)\&from=EN.

${ }^{83}$ Article 129.4. Ibid.

${ }^{84}$ Article 129.3. Ibid.

${ }^{85}$ Article 129.6. Ibid.

${ }^{86}$ Article 129.7. Ibid.

${ }^{87}$ Article 42(7), Lisbon Treaty. European Commission, "Consolidated Version of the Treaty on European Union".

${ }^{88}$ Article 222, Treaty on the Functioning of the EU. European Commission, "Consolidated version of the Treaty on the Functioning of the European Union", Official Journal of the European Union, C 326/1, October 26, 2012.

${ }^{89}$ Third countries (including non-EU European allies) can take part in EU operations though either a Framework Participation Agreement or on a case-by case basis. In case of a need, third countries are also expected to conclude an agreement to exchange classified information with the EU. 
arrangement. ${ }^{90}$ However, they do not have decision-making rights in the CSDP but they might perform decision-shaping through various consultation mechanisms.

The UK's future participation in the CFSP/CSDP is a contentious issue. The UK would be reluctant to participate in CSDP operations or bodies/programmes such as EDA if it were not given a say over the CSDP after a possible deal. ${ }^{91}$ However, the Turkish case has already shown that the EU is very fond of its decision-making autonomy and would not let a third country have any decision-making rights. ${ }^{92}$ The EU's stance might thus make the UK tend towards improving its bilateral relations ${ }^{93}$ with the EU member states or enter into multinational arrangements ${ }^{94}$ with them. The UK's outright support for the EII can also be evaluated within this context. ${ }^{95}$ Nevertheless, the EII might have the impact of leading to more divisions within the EU in the long run because of its exclusive nature. On the other hand, Brexit also means that the only platform of discussion on European defence left for the UK and the EU will be NATO ${ }^{96}$ if no deal is reached on the UK's participation in the CSDP. This might have the consequence of improving NATO-EU cooperation - although this might not be possible in the short and medium run due to double vetoes of Turkey and Cyprus ${ }^{97}$.

90 Note that Turkey cannot join the work of EDA due to Greek Cypriot veto.

91 In February 2018, in her Munich Security Conference Speech, British PM Theresa May called for a deep and special partnership with the UK, underlining that "the UK must be able to play an appropriate role in shaping" collective actions in the realm of security and defence. Gov.uk, "PM Speech at Munich Security Conference", February 17, 2018. Accessed on October 20, 2019, https:/www.gov.uk/government/speeches/pm-speech-at-munichsecurity-conference-17-february-2018. Boris Johnson's policy, on the other hand, seems rather ambivalent.

92 For more on Turkey's involvement in ESDP/CDSP see: Münevver Cebeci, "NATO-EU Cooperation and Turkey", Turkish Policy Quarterly 10, no 3 (2011): 93-103. http://www.turkishpolicy.com/dosyalar/files/Munevver\%20Cebeci(1).pdf

93 The UK already has certain bilateral security and defence agreements with EU member states, the most famous one being the Lancaster House Treaties signed with France in 2010. The most important product of the Lancaster House Treaties is the creation of Combined Joint Expeditionary Force (CJEF) that became operational in 2020.

94 E.g., the Comprehensive Memorandum of Understanding at Lancaster House was signed in June 2018 which resulted in the creation of a Joint Expeditionary Force (JEF) a force separate from but complementary to NATO. The framework nation of JEF is the UK and the participating countries are: Denmark, Estonia, Finland, Latvia, Lithuania, the Netherlands, Norway and Sweden.

95 Turpin, "UK-EU Military Cooperation and Brexit", 19.

96 Cf. Martill and Sus, "Post-Brexit EU/UK security cooperation", 856.

97 Turkey does not recognize Cyprus as a state. 


\section{Evaluating the EU's Security and Defence Actorness after Brexit}

This section examines Brexit's impact on the EU's security and defence actorness through the three factors that affect global actorness defined by Bretherton and Vogler. It first looks into the external and internal context, with a slight twist to their notion of "opportunity" as explained in the introduction. First, the external and internal context are analysed by looking into the developments that took place simultaneously with Brexit and thus amplified its impact on the EU's actorness. Then Brexit's impact is evaluated in terms of the EU's presence and capabilities.

\section{External and Internal Contexts}

Brexit took place at a time when the external context was rather challenging for the EU. On the one hand, these external challenges, coupled with Brexit, have had a limiting impact on the EU's actorness. On the other hand, they represented opportunities because they forced the Member States to deal with them through enhancing security and defence cooperation and developing EU strategic autonomy.

When we consider the impact of the global level on the EU, what comes to the fore is the position of the US, as the dominant actor in international relations. The election of Donald Trump as the US President in 2016 and his coming into power in January 2017 has amplified the impact of Brexit. His ambivalent and unpredictable approach towards transatlantic relations, his criticisms against European allies regarding Transatlantic burden-sharing, and his statements that even NATO's relevance could be questioned if European Allies did not spend more on defence ${ }^{98}$ have demonstrated that the US was no longer a reliable ally to the $\mathrm{EU}^{99}$. This has impelled the Europeans to take more decisive steps toward strategic autonomy.

Regional challenges such as the mass flow of refugees to Europe after the Arab uprisings and the Syrian civil war, the Libyan civil war, the Ukrainian

98 See, e.g., The White House, "Remarks by President Trump at NATO Unveiling of the Article 5 and Berlin Wall Memorials - Brussels, Belgium", May 25, 2017. Accessed on April 24, 2019, https://www.whitehouse.gov/briefings-statements/remarks-presidenttrump-nato-unveiling-article-5-berlin-wall-memorials-brussels-belgium/.

99 This did not start with Trump because the US focus had already shifted to Asia-Pacific during the Obama Presidency urging the Europeans to take more responsibility on their own defence, but Trump's unpredictable behaviour heightened the European doubts. See, e.g., Nick Amies, "Asia Pacific region becomes main focus of US foreign policy", Deutsche Welle, November 17, 2011. Accessed on April 23, 2019, https://www.dw.com/en/asiapacific-region-becomes-main-focus-of-us-foreign-policy/a-15522953. 
crisis and Russia's increasingly aggressive behaviour have also affected the EU's actorness, as dealing with them has required diversified capabilities ranging from humanitarian and rescue to hybrid warfare. The mass flow of refugees to Europe had military implications, especially in terms of border management and naval engagement to disrupt human smuggling and trafficking. Russia's annexation of Crimea and the unrest in Eastern Ukraine have also compelled the EU to improve its CSDP.

At the bilateral/inter-unit level, the emergence of other actors also curbed the EU's effectiveness in its security and defence policies. Actors such as Russia, China and Turkey have gotten more and more engaged in providing humanitarian and development aid to the major areas of EU influence such as North Africa, the Middle East and Sub-Saharan Africa. These actors are increasingly becoming engaged militarily in these regions as well - a factor that represents a strategic challenge to the EU. With Brexit, one of those countries might even become the UK as a new neighbour and a regional player with overseas capabilities and a stake, especially in the Mediterranean. The UK might also challenge the EU's actorness in certain regions if no Brexit deal is reached. If a deal can be reached, this might then enhance both parties' actorness.

The internal context during the whole process of Brexit was not very favourable for the EU as well. The Brexit itself has been the major internal development with serious consequences as elucidated here. Brexit took place at a time when the EU had only recently come out of the Eurozone crisis that significantly decreased its attractiveness to other states and societies as an area of welfare, affecting its presence. On the other hand, EU member states were reluctant at best, or not capable at worst, to increase their defence capabilities as envisaged by the Lisbon Treaty ${ }^{100}$ and the Global Strategy ${ }^{101}$. The already existing divides in the EU, such as the Transatlanticist-Europeanist divide, and Frances's ambivalent behaviour has also continued to affect the CSDP. During the Brexit process, the internal context had been favourable to develop certain mechanisms and improve existing ones for further defence integration in the EU, because the UK was the major Member State openly blocking these mechanisms. Nevertheless, these did not take happen without any challenges or contestation. The Franco-German divergences on the new shape of PESCO and the creation of the EII are important examples in this regard. All in all, whether Brexit will be an opportunity for the EU to enhance its actorness or

${ }^{100}$ Article 42(3). European Commission, "Consolidated Version of the Treaty on European Union".

${ }^{101}$ European External Action Service, "Shared Vision, Common Action”, 20-21. 
become a limiting factor under these conditions remains to be seen. This will depend on several factors such as, (and mainly) the member states' political will to pursue the EU's strategic autonomy, and, the UK and the EU's resolve to reach a Brexit deal.

\section{Presence}

Bretherton and Vogler define presence as "the ability of an actor, by virtue of its existence, to exert influence beyond its borders", underlining that this "does not denote purposive external action, rather it is the ability to shape the perceptions, expectations and behaviour of others". ${ }^{102}$ In their view, being a successful regional integration process with significant welfare, the EU has attracted third countries and made them change their behaviour, not necessarily having the purpose of having a foreign policy impact. Britain has significantly contributed to the EU's presence with its economic power (as one of the major donors of humanitarian and development aid), its worldwide diplomatic network and experience (i.e., its diplomatic weight), its overseas influence, its permanent seat at the UNSC, and its military capabilities (including nuclear power). Brexit has thus significantly diminished the EU's presence. First and foremost, the successful regional integration narrative has been cracked (as Brexit is a story of fragmentation). Second, the loss of a power with such diplomatic weight and experience goes beyond a simple loss of capabilities. It is an issue of presence as the other actors' perceptions of the $\mathrm{EU}$ and its weight and representation as an actor has changed.

Turpin states that Brexit has caused a "loss of credibility brought about by the loss of British input into CSDP structures"103. In Major and Mölling's view, "Brexit might create a more fragmented and inward-looking EU with less political unity and credibility" and "this potentially [reduces the EU's capacity] to shape political developments"104. These arguments can all be interpreted within the framework of presence as successful integration made the EU attractive to others to engage in closer relations. ${ }^{105}$ Coupled with a set of crises that the EU has gone through such as the Eurozone crisis and the Member States' diverging approaches to the mass flow of refugees from the

102 Bretherton and Vogler, “A Global Actor Past Its Peak?”, 376.

103 Turpin, "UK-EU Military Cooperation and Brexit", 19.

${ }^{104}$ Claudia Mjor and Christian Mölling, "Brexit, Security and Defence: A political problem, not a military one", UI Brief 3, 2017, 1-2.

${ }^{105}$ Mjor and Mölling argue: "Brexit questions the very logic and hitherto accepted truths and myths of European integration: that it is irreversible, attractive to everybody, and only develops in one direction - deeper in each area that it governs and further in expanding the number of areas that it comprises." Ibid., 3 . 
Middle East and North Africa and to Russian aggression in Ukraine, Brexit has significantly eroded the EU's attractiveness and credibility.

A crucial attempt to enhance the EU's presence has been the announcement of the Global Strategy. The Strategy was mainly a response to the criticisms that the EU could not display unity in its external action and did not have a strategic orientation. The Brexit referendum was not one of the reasons that led to the drawing up of the Strategy, but the timing with which it was announced was significant and this can also be seen in its foreword by the then High Representative Mogherini:

In challenging times, a strong Union is one that thinks strategically, shares a vision and acts together. This is even more true after the British referendum. We will indeed have to rethink the way our Union works, but we perfectly know what to work for. We know what our principles, our interests and our priorities are. This is no time for uncertainty: our Union needs a Strategy. We need a shared vision, and common action. ${ }^{106}$

Mogherini's statement demonstrates the need felt after Brexit to reassure the European public and the world that the EU would continue to exist as what it used to be and pursue the same principles and interests. Thus, the Strategy served as a tool to show the world that the EU can still display unity and work towards strategic autonomy after Brexit.

In security and defence terms, global actorness is closely related with the capability to project power globally. Military capabilities are not only operationally important but they also have an impact in terms of their existence. They have a political impact that significantly contributes to an actor's presence. Although it was not what Bretherton and Vogler meant when they defined the EU's presence initially, still, security and defence actorness can be defined on these lines. Waever draws attention to the identity aspect of success in security and defence policies, contending that this would significantly add to the new European generations' identification with the EU. ${ }^{107}$ How the world perceives the EU also depends on its success in the security and defence realm. Thus, it can be argued that Brexit has a significant impact on the EU's presence, even more than its impact on the EU's capabilities.

\footnotetext{
${ }^{106}$ European External Action Service, "Shared Vision, Common Action", 3.

${ }^{107}$ Ole Waever, "Integration as security - Constructing a Europe at Peace", in Atlantic Security - Contending Visions, ed. Charles A. Kupchan (New York: Council of Foreign Relations, 1998), 59-60.
} 


\section{Capability}

As defined by Bretherton and Vogler, capability is mainly about the "availability of, and capacity to utilize, policy instruments-diplomacy/ negotiation, economic tools and military means" and "[t]he ability to identify priorities and formulate policies", besides "a shared commitment to" values and "domestic legitimation" of EU policies. Brexit's major impact on the EU's capabilities has been the decrease in the numbers of certain military equipment and personnel and the loss of significant diplomatic and military expertise/experience ${ }^{108}$.

In terms of the EU's ability to identify priorities and formulate policies, Brexit's impact can be felt concerning the shift of balance in the Transatlanticist-Europeanist divide which might and has already paved the way for institutional and capability development in the CSDP. This seems to be a positive impact in the short-run. However, the French stance will mostly determine the course of the CSDP in the medium and long-term as its insistence on intergovernmentalism in this area and its preference for other exclusive initiatives such as the EII might be divisive and lead to fragmentation at some point. Here a balancing factor might be the coleadership of the CSDP by France and Germany where Germany would constrain French moves that might destabilize the CSDP. Nevertheless, France and Germany also have significant divergences in their approach to European security and defence. Thus, this co-leadership is not also without problems, as Germany favours a more inclusive supranational framework whereas France prefers an exclusive and intergovernmental approach to CSDP.

Regarding the availability of instruments and the capacity to use them, a first look might suggest that the loss of the UK's capabilities is the most visible effect of Brexit. The UK has significant air, naval and land capabilities as well as intelligence, surveillance, and reconnaissance capabilities. It also has the experience to conduct the full range of military operations and offer headquarters to multinational operations. Brexit, thus, "on paper", means the EU's loss of approximately 20 per cent of its capabilities. ${ }^{109}$ Nevertheless,

${ }^{108}$ See, eg., Simon Duke, “Capabilities and CSDP: resourcing political will or paper armies?”, in Research Handbook on the EU's Common Foreign and Security Policy, ed.s Steven Blockmans and Panos Koutrakos, (Cheltenham and Northampton: Edward Elgar Publishing, 2018), 179.

${ }^{109}$ Claudia Major and Alicia von Voss, "European Defence in View of Brexit", SWP Comments 10, (April 2017), 2. Accessed on October 25, 2019, https://www.swpberlin.org/fileadmin/contents/products/comments/2017C10_mjr_vos.pdf. Also see: Jamie 
when one considers that Britain had long decreased its military involvement in the CSDP and its contributions have never been commensurate with its military power; in effect, the loss might not be that big. An EP Study on the Brexit's impact thus argues:

When the British will leave the EU, the civilian and military crisis management missions under the CSDP as currently carried out are not expected to suffer dramatic consequences. [...] The personnel deployed by the UK in 2017 in the framework of the CSDP has been estimated at between 100 and 150 people, although the country deploys a total of 13 000 soldiers overseas. Looking at these figures, then, the British do not look irreplaceable to the EU. ${ }^{110}$

Various researchers also verify the EP's argument. For example, Major and von Voss contend that "Brexit is likely to have little effect on the CSDP" when compared to other EU policy realms and that its "political clout" might be bigger ${ }^{111}$. The UK had blocked the creation of operational headquarters for CSDP for a long time and also vetoed an increase in EDA budget. Thus Brexit's impact in terms of capabilities might not be that negative. The recent steps taken by EU Member States for strategic autonomy such as the activation of PESCO, creation of the EDF and CARD and also the establishment of the MPSS as the EU's operational headquarters (albeit symbolic) testify to this argument. Nevertheless, it remains to be seen whether the Member States will be able to maintain and enhance these structures in the medium and long terms and whether they will support and ensure their functioning despite their diverging views on the future of European defence. Turpin argues that "the main question is the capacity of the EU to translate recent promising steps on defence into concrete contributions of greater military capabilities, interoperability, and deployability." 112 This depends mainly on the political will of the Member States as underlined by the then High Representative Mogherini: "The instruments we have set up have an immense potential, but it is now up to us to make full use of this potential. It is a matter of political will, particularly from Member States." 113

Shea, "European Defence After Brexit: A Plus or a Minus?", European View 19, no 1 (2020): 88-89.

${ }^{110}$ European Parliament, "CSDP after Brexit”, 33.

${ }^{111}$ Major and von Voss, "European Defence in View of Brexit", 1-2.

112 Turpin, "UK-EU Military Cooperation and Brexit", 25.

${ }^{113}$ European University Institute, "Address - European University Institute's State of the Union”, The State of the Union - Keynote Speeches, May 14, 2018. Accessed on October $20 \quad$ 2019, https://sou-pasteditions.eui.eu/wpcontent/uploads/sites/9/2018/05/SpeechMogherini.pdf. 


\section{Conclusion}

The EU's actorness has been a long-debated issue. Brexit came at a time when the EU was faced with multiple challenges at the global, regional and domestic levels. Its impact on the EU has become widely discussed and a vast literature has developed around it. Nevertheless, a conceptual analysis of its impact on the EU's global actorness has been missing. This article has attempted to fill the void in the literature by looking into how Brexit has affected the EU's security and defence actorness. Adopting Bretherton and Vogler's conception of global actorness, it has shown that Brexit has caused a significant loss for the EU in terms of both its capabilities and presence; nevertheless, the loss in terms of capabilities has not been as grave as expected and the damage done to the EU's presence has been bigger. Brexit's future implications will depend on whether the UK and the EU will be able to reach a deal. In the case of a no-deal, the negative implications might be higher and can bring about new hurdles to the EU in terms of the context in which it tries to pursue its policies.

The body of literature that revolves around Brexit's impact on the EU's security and defence policies testifies to Waever's claim that by contemplating and writing on the EU's foreign and security policies and assessing its actorness on the lines of "failure, doubt and ambivalence" as much as on action and success, we have already constructed it as an actor. This article has been an attempt at approaching the impact of Brexit on the CSDP through a conceptual lens. Future studies might take this conceptual analysis further by looking at the impact of Brexit on the EU's civilian crisis management, on European defence industry, which also has a supranational/trade dimension, and also on the CFSP in general.

\section{References}

Amies, Nick. "Asia Pacific region becomes main focus of US foreign policy", Deutsche Welle, November 17, 2011. Accessed on April 23, 2019. https://www.dw.com/en/asia-pacific-region-becomes-main-focus-of-usforeign-policy/a-15522953.

Angelini, Lorenzo. Brexit is an opportunity for EU defence policy", EU Observer, July 8, 2016. Accessed on April 23, 2020, https://euobserver.com/opinion/134256

Axe, David. "Commentary: What the U.S. should learn from Britain's dying navy", Reuters, 14 (October 2016). Accessed on August 30. https://www.reuters.com/article/us-uk-military-navy-commentaryidUSKCN10L1AD. 
Bakker, Anne and Margriet Drent and Dick Zandee. "European defence: how to engage the UK after Brexit?", Clingendael Report, 15 (July 2017). Accessed on May 19, 2019. https://www.clingendael.org/sites/default/files/201707/Report_European_defence_after_Brexit.pdf.

Biscop, Sven. "Brexit, Strategy, and the EU: Britain Takes Leave", Egmont Papers 100, (2018), 10-11

Biscop, Sven."All or nothing? The EU Global Strategy and defence policy after the Brexit”, Contemporary Security Policy 37, no 3 (2016): 431-445

Bretherton, Charlotte and John Vogler. “A Global Actor Past Its Peak?”, International Relations 27, no 3, 375-390.

Bretherton, Charlotte and John Vogler. The European Union as a Global Actor, London and New York: Routledge, 1999.

Bretherton, Charlotte and John Vogler. The European Union as a Global Actor, London and New York: Routledge, 2006.

Cebeci, Münevver. "NATO-EU Cooperation and Turkey”, Turkish Policy Quarterly 10, no 3 (2011): 93-103. Accessed on April 20, 2019. http://www.turkishpolicy.com/dosyalar/files/Munevver\%20Cebeci(1).pdf

Chalmers, Malcolm. "Brexit and European Security", RUSI Briefing Paper, February 2018. Accessed on October 29, 2019, https://rusi.org/sites/default/files/20180223_malcolm_brexit_security_v4.pdf.

Collier, David. "Understanding Process Tracing”, Political Science and Politics 44, no 4 (2011): 823-30.

Council of the European Union. "Council conclusions on Security and Defence in the context of the EU Global Strategy - Council conclusions (19 November 2018)", Brussels, 13978/18, November 19, 2018. Accessed on October 25, 2020, https:/data.consilium.europa.eu/doc/document/ST-13978-2018-INIT/en/pdf.

Duke, Simon. “Capabilities and CSDP: resourcing political will or paper armies?”, in Research Handbook on the EU's Common Foreign and Security Policy, ed.s Steven Blockmans and Panos Koutrakos, 154-81. Cheltenham and Northampton: Edward Elgar Publishing, 2018.

Élysée. "Meseberg Declaration - Renewing Europe's promises of security and prosperity", June 19, 2018. Accessed on October 29, 2019, https://www.elysee.fr/emmanuel-macron/2018/06/19/meseberg-declarationrenewing-europes-promises-of-security-and-prosperity.en.

European Commission. "Agreement on the withdrawal of the United Kingdom of Great Britain and Northern Ireland from the European Union and the European Atomic Energy Community", Official Journal, 2019/C 384 I/1, November 12, 2019. Accessed on November 30, 2019. https://eur-lex.europa.eu/legalcontent/EN/TXT/PDF/?uri=CELEX:12019W/TXT(02)\&from=EN. 
European Commission. "Consolidated Version of the Treaty on European Union", Official Journal of the European Union, C 326/1, October 26, 2012.

European Commission. "Council Decision (CFSP) 2020/1639 of 5 November 2020 establishing the general conditions under which third States could exceptionally be invited to participate in individual PESCO projects", Official Journal of the European Union, November 6, 2020. Accessed on November 14, 2020. https://eur-lex.europa.eu/eli/dec/2020/1639/oj.

European Commission. "European Defence Fund", Factsheet, March 19, 2019. Accessed on October 29, 2019. https://ec.europa.eu/docsroom/documents/34509/attachments/1/translations/en/ renditions/native.

European Commission. "State of the Union 2018 - The Hour of European Sovereignty", September 12, 2018. Accessed on May 19, 2020. https://ec.europa.eu/commission/sites/beta-political/files/soteu2018speech_en.pdf.

European Commission. "State of the Union Address 2016: Towards a better Europe a Europe that protects, empowers and defends", September 14, 2016. Accessed on October 29, 2019. https://ec.europa.eu/commission/presscorner/detail/en/SPEECH_16_3043.

European Defence Agency. "2016 Annual Accounts", June 30, 2017. Accessed on May 18, 2019. https://eda.europa.eu/docs/default-source/financedocuments/eda-2016-annual-accounts.pdf.

European Defence Agency. “Annual Report 2019”, 2020. Accessed on October 29, 2020, https://www.eda.europa.eu/docs/default-source/eda-annual-reports/eda2019-annual-report.

European Defence Agency. "Coordinated Annual Review on Defence (CARD)", 2020: Accessed on April 23, 2020. https://www.eda.europa.eu/what-we-do/ourcurrent-priorities/coordinated-annual-review-on-defence-(card).

European Defence Agency. "Finance", 2020. Accessed on October 29, 2020. https://eda.europa.eu/Aboutus/who-we-are/Finance.

European External Action Service. "Shared Vision, Common Action: A Stronger Europe - A Global Strategy for the European Union's Foreign and Security Policy", June 2016. Accessed on August 30, 2016. https://eeas.europa.eu/archives/docs/top_stories/pdf/eugs_review_web.pdf.

European External Action Service. "The Military Planning and Conduct Capability (MPCC)", November 2018. Accessed on May 19, 2019. https://eeas.europa.eu/sites/eeas/files/mpcc_factsheet_november_2018.pdf. 
European External Action Service. "Permanent Structured Cooperation - PESCO", Factsheet, June 2018. Accessed on August 13, 2018. https://eeas.europa.eu/sites/eeas/files/pesco_

factsheet_22-06-2018_2.pdf.

European External Action Service. “The European Union's Global Strategy: three years on, looking forward", June 2019. Accessed on October 29, 2019. https:/eeas.europa.eu/sites/eeas/files/eu_global_strategy_2019.pdf.

European External Action Service. "Permanent Structured Cooperation - PESCO", Factsheet, November 2020. Accessed on November 27, 2020. https://eeas.europa.eu/sites/eeas/files/pesco_factsheet_2020-11-9-version-20nov.pdf.

European Parliament. "CSDP after Brexit: the way forward”, Study, May 2018. Accessed on April 2020. https://www.europarl.europa.eu/RegData/etudes/STUD/2018/603852/EXPO_S TU(2018)603852_EN.pdf.

European Union Institute for Security Studies - EU-ISS. "Franco-British Summit Le Touquet, 4 February 2003", From Copenhagen to Brussels - European defence: core documents, Volume IV, Chaillot Papers 67 (December 2003): 3639.

European University Institute. “Address - European University Institute's State of the Union”, The State of the Union - Keynote Speeches, May 14, 2018. Accessed on October 20, 2019, https://sou-pasteditions.eui.eu/wpcontent/uploads/sites/9/2018/05/SpeechMogherini.pdf.

Faleg, Giovanni."The Implications of Brexit for the EU's Common Security and Defence Policy”. CEPS Policy Contribution, July 26, 2016. Accessed on August 15, 2019. https://www.ceps.eu/ceps-publications/implications-brexit-euscommon-security-and-defence-policy/.

France 24. "Nine EU countries sign up for European military intervention plan", June 25, 2018. Accessed on October 25, 2019. https:/www.france24.com/en/20180625-nine-eu-countries-sign-europeanmilitary-intervention-plan.

France Diplomacy. "President Macron's Initiative for Europe: A sovereign, united, democratic Europe", September 26, 2017. Accessed on October 25, 2019. https:/www.diplomatie.gouv.fr/en/french-foreignpolicy/europe/news/article/president-macron-s-initiative-for-europe-asovereign-united-democratic-europe.

George, Alexander L. and Andrew Bennett. Case Studies and Theory Development in the Social Sciences, Cambridge, MA: MIT Press, 2005. 
Giegerich, Bastian and Christian Mölling. “The United Kingdom's contribution to European security and defence", DGAP External Publications, February 7, 2018. Accessed on October 20, 2020. https://dgap.org/system/files/article_pdfs/the_united_kingdoms_contribution_t o_european_security_and_defence.pdf.

Gov.uk. "PM Speech at Munich Security Conference", February 17, 2018. Accessed on October 20, 2019, https://www.gov.uk/government/speeches/pm-speech-atmunich-security-conference-17-february-2018.

Gov.uk. "Participating in EU satellite and space programmes from 1 January 2021", October 9, 2020. Accessed on October 29, 2020, https:/www.gov.uk/guidance/satellites-and-space-programmes-from-1january2021\#: :text=The $\% 20$ UK\%20will\%20not\%3A,in\%20the $\% 20$ development $\% 2$ 0of $\% 20$ Galileo

Heisbourg, François. "Brexit and European Security", Survival 58, no 3 (2016): 13 22.

Heisbourg, François. "Europe's Defence: Revisiting the Impact of Brexit", Survival 60, no 6 (2018): 17-26.

Hill, Christopher. "The Capability-Expectations Gap, or Conceptualizing Europe's International Role", Journal of Common Market Studies 31, no 3 (1993): 305 328 .

Iso-Markku, Tuomas and Gisela Müller-Brandeck-Bocquet. "Towards German leadership? Germany's Evolving Role and the EU's Common Security and Defence Policy", German Politics 29, no 1 (2020): 59-78.

"Joint Declaration on European Defence", Joint Declaration of the Heads of State and Government of France and the United Kingdom issued at the British-French summit, St Malo, 3-4 December 1998, https://www.cvce.eu/content/publication/2008/3/31/f3cd16fb-fc37-4d52-936fc8e9bc80f24f/publishable_en.pdf.

Körber-Stiftung. "Einmischen oder zurückhalten? Eine repräsentative Umfrage im Auftrag der Körber-Stiftung zur Sicht der Deutschen auf die Außenpolitik", (2019), https://www.koerber-stiftung.de/fileadmin/user_upload/koerberstiftung/redaktion/handlungsfeld_internationaleverstaendigung/pdf/2019/Umfrage_Einmischen_oder_zuru_ckhalten.pdf.

Lindstrom, Gustav. "Enter the Battle Groups", Chaillot Papers 97 (February 2007).

Mauro, Frédéric. "The European Intervention Initiative: Why we should listen to German Chancellor Merkel", IRIS Tribune, July 16, 2018. Accessed on October 29, 2019, https://www.iris-france.org/115776-the-european-interventioninitiative-why-we-should-listen-to-german-chancellor-merkel/. 
Major, Claudia and Alicia von Voss. "European Defence in View of Brexit", SWP Comments 10, April 2017. Accessed on October 25, 2019, https://www.swpberlin.org/fileadmin/contents/products/comments/2017C10_mjr_vos.pdf.

Major, Claudia and Christian Mölling. "Brexit, Security and Defence: A political problem, not a military one", UI Brief 3, 2017.

Major, Claudia and Christian Mölling. "Franco-German Differences Over Defense Make Europe Vulnerable”, Judy Dempsey's Strategic Europe, March 29, 2018. Accessed on August 30, 2019, https://carnegieeurope.eu/strategiceurope/75937

Martill, Benjamin, and Monika Sus. "Post-Brexit EU/UK security cooperation: NATO, CSDP+, or 'French connection'?”, The British Journal of Politics and International Relations 20, no 4 (2018): 846-63.

NATO. "Defence Expenditure of NATO Countries (2013-2019)", Press Release, November 29, 2019. Accessed on April 23, 2020. https://www.nato.int/nato_static_fl2014/assets/pdf/pdf_2019_11/20191129_pr2019-123-en.pdf.

Reuters. "Britain confirms withdrawal from EU military missions, diplomats say", October 21, 2020. Accessed on October 29, 2020. https://www.reuters.com/article/uk-britain-eu-defence-idUSKBN2761VU.

Shea, Jamie. "European Defence After Brexit: A Plus or a Minus?", European View 19, no 1 (2020): 88-94

Sjöstedt, Gunnar. The External Role of the European Community. Westmead: Saxon House, 1977.

The Federal Government. "The White Paper on German Security Policy and the Future of the Bundeswehr", July 13, 2020. Accessed on October 29, 2020. https://issat.dcaf.ch/download/111704/2027268/2016\%20White\%20Paper.pdf.

The UK Ministry of Defence, “UK Defence in Numbers - 2019”, (2019). Accessed on $\quad$ April 23, 2020. https://assets.publishing.service.gov.uk/government/uploads/system/uploads/att achment_data/file/869612/20200227_CH_UK_Defence_in_Numbers_2019.pd f.

The White House. "Remarks by President Trump at NATO Unveiling of the Article 5 and Berlin Wall Memorials - Brussels, Belgium", May 25, 2017. Accessed on April 24, 2019. https://www.whitehouse.gov/briefings-statements/remarkspresident-trump-nato-unveiling-article-5-berlin-wall-memorials-brusselsbelgium/.

Turpin, Lee David. "UK-EU Military Cooperation and Brexit from a Neoclassical Realist Perspective: No Big Deal?”, in Peace, Security and Defence Cooperation in Post-Brexit Europe - Risks and Opportunities, ed.s Cornelia-Adriana Baciu and John Doyle, 3-27. Cham: Springer Nature, 2019. 
Waever, Ole. "Securitization and Desecuritization", in On Security, ed. Ronnie D. Lipshutz, 46-86. New York: Columbia University Press, 1995.

Waever, Ole. "Integration as security - Constructing a Europe at Peace", in Atlantic Security - Contending Visions, ed. Charles A. Kupchan, 45-63. New York: Council of Foreign Relations, 1998.

Waever, Ole. "The EU as a security actor - Reflections from a pessimistic constructivist on post-sovereign security orders" in International Relations Theory and the Politics of European Integration - Power, Security and Community, ed. Morten Kelstrup, and Michael C. Williams, 250-294. London and New York: Routledge, 2000.

Waterfield, Bruno. "Britain blocks EU plans for 'operational military headquarters", The Telegraph, July 18, 2011. Accessed on April 23, 2019. https://www.telegraph.co.uk/news/worldnews/europe/eu/8645749/Britainblocks-EU-plans-for-operational-military-headquarters.html.

Whitman, Richard. "Defence on the Brexit frontline", Open Democracy, March 11, 2016. Accessed on April 23, 2019. https://www.opendemocracy.net/en/brexitdivisions/defence-on-brexit-frontline/.

Zandee, Dick and Kimberley Kruijver. "The European Intervention Initiative Developing a shared strategic culture for European defence", Clingendael Report, (September 2019). Accessed on October 29, 2019. https://www.clingendael.org/sites/default/files/2019-

09/The_European_Intervention_2019.pdf. 